\title{
THE INCREASING YIELD AND QUALITY OF WAXY CORN (Zea mays ceratina L.) THROUGH COCONUT ASH ORGANIC FERTILIZER APPLICATIONS
}

\author{
Marianne Reynelda Mamondol ${ }^{1)}$ and Nurfhin Ilma Bunga ${ }^{2)}$ \\ ${ }^{1,2}$ Faculty of Agriculture Tentena Christian University \\ e-mail : mariannemamondol@ymail.com
}

\begin{abstract}
This research aims to find out the effect and functional relationship of coconut ash organic fertilizer application on the increasing yield and quality of waxy corn. There are seven treatments of coconut ash fertilizer dosage, i.e. $0.00 \mathrm{ton} / \mathrm{ha}, 0.75 \mathrm{ton} / \mathrm{ha}, 1.50 \mathrm{ton} / \mathrm{ha}, 2.25 \mathrm{ton} / \mathrm{ha}, 3.00 \mathrm{ton} / \mathrm{ha}, 3.75 \mathrm{ton} / \mathrm{ha}$, and $4.50 \mathrm{ton} / \mathrm{ha}$. Data is analyzed using one way anova, t test for 2 independent samples, and simple linear regression analysis. Fertilizer dosage has significant effect on ear height position from soil surface, the number of seed row on ear, ear weight with and without dried husk, waxy corn production with and without dried husk, and starch, amilose, and amilopectin contents. The highest average of ear height position and the amount of seed row is obtained at dosage 0.75 ton/ha. Dosage 2.25 ton/ha gives highest average for ear weight with and without dried husk, while dosage 3.75 ton/ha results highest average for variables of waxy corn production with and without dried husk. Dosage 3.75 ton/ha also gives highest average for starch and amilopectin contents and lowest average for amilose content. One way relationship happens between fertilizer dosage with ear height position, the amount of seed row, ear weight, waxy corn production, starch and amilopectin contents.
\end{abstract}

Keywords: waxy corn, coconut ash, yield, quality

\section{INTRODUCTION}

Waxy corn (Zea mays ceratina L.) is a type of specific corn which needed increasingly at the present time by either consumers or industries. This specific corn leads in high contents of certain functional substances. Waxy corn has more delicious, smoother, and softer taste. The taste emerges due to high amilopectin content in waxy corn seed as many as $90 \%$ or even can reach $100 \%$ (Suarni, 2009).

Waxy corn constitutes typical foodstuff of Sulawesi Island. Generally, Sulawesi people like waxy corn very much and create it in various forms of processed foods. In addition, waxy corn also becomes the source of germ plasma to arrange new cultivars through plant breeding (Azrai et al, 2009). Market demand for waxy corn continues to grow over time, but this can not be matched by production. According to Suarni (2013), local waxy corn of Sulawesi had productivity that reached only
2 to 2.5 ton/ha, while yield potential could reach 8.09 ton/ha. At Poso Regency in the year of 2012, waxy corn production could only attain 3,731.2 ton, lower than production at Central Sulawesi level which achieved 440.308 ton (BPS Poso, 2013).

Efforts to enhance crop production can be undertaken by expanding planting area, increasing crop productivity, maintaining production stability, suppressing yield gap, and reducing yield loss. Besides, enhancing crop productivity also depends on the ability of provision and cultivation technology application that suits to recommendation, such as fertilizer using.

Fertilizer application with right dosage is one way to raise waxy corn production. Fertilizing is an act to give nutrient to crops through soil as crop growing media. Kalium $(\mathrm{K})$ is a macro nutrient which essential for crop growing and production. Jumin (2010) stated that $\mathrm{K}$ was needed for carbohydrate formation and sugar translocation process in plant as well as to add seed weight of cereal crops . 
Kalium fertilization can also be performed organically by benefiting natural materials with purposes to enhance crop growing and production, to improve soils chemically, physically, an biologically, and to avoid pollution because natural materials are environmentally friendly (Nurhayati et al, 2011). There are natural materials that rich with $\mathrm{K}$ content, including coconut fiber. Poso Regency is a coconut producing region, but coconut fiber still becomes agricultural waste that its benefits has not been known much yet by people. Whereas coconut fiber is able to be processed as raw material for organic fertilizer production and ultimately be applied to crops (Hermawati, 2007).

Based on the above explanation, it is necessary to conduct investigation about the application of coconut ash as organic kalium fertilizer with certain dosages on waxy corn and to observe the effect of fertilization on increasing yield and quality of waxy corn. The aims of this study are : 1) to analyze the effect of coconut ash fertilizer dosage on waxy corn's increasing yield and quality, and 2) to analyze functional relationship between coconut ash fertilizer dosage with waxy corn's yield and quality.

\section{LITERATURE REVIEW}

\section{The Characteristics of Waxy Corn Seed}

Waxy corn is one of corn types which often used as staple food to substitute rice by people who inhabit Sulawesi Island. People are fond of this corn due to its sticky-like and delicious flavour compares to another types of corn. Waxy corn is consumed by boiling or baking the ears, or by making shells and cooking them with vegetables (Suarni, 2009).

Delicious taste in waxy corn is induced by amilopectin content in waxy corn seed that can reach 93 to $100 \%$ of seed weight (Suarni, 2009). Amilopectin is a long and branched polysaccharide and jointed by glycocydic bunddle $\alpha(1 \rightarrow 4)$ at its straight chain and $\alpha-1,6$ bunddle at the branches (Lakitan, 2011). Amilopectin content effects the texture and flavour of waxy corn. Principally, the higher the content, the softer, stickier, and more delicious the texture and taste. High amilopectin content can cause waxy corn contains high food fibre as well. Food fibre has important roles in maintaining individual health (Suarni, 2009).

\section{Organic K Ferlitization on Crops}

According to Farizaldi (2014), K fertilization to crops benefited in enhancing crop vigor, making crop more resistant to diseases, resulting better roots, decreasing negative effect of nitrogen $(\mathrm{N})$ fertilization, influencing maturity period which perhaps more rapidly due to phosphor $(\mathrm{P})$ fertilization, regulating the balance of $\mathrm{N}$ and $\mathrm{P}$ fertilizers particuarly in mixed fertilization, assisting carbohydrate formation and sugar translocation process in crop, and increasing cereal seed weight so that the yield will be more filled out.

Pradana et al (2015) confirmed that K substances were absorbed by crop in the form of $\mathrm{K}^{+}$ion, where the substances existed in soils in complex compounds and were binded by minerals or salt solutions. The increasing of $\mathrm{N}$ and $\mathrm{P}$ fertilizer applications will raise the $\mathrm{K}$ application as well. $\mathrm{K}$ fertilizer gives significant effect on dry soils, but on wetlands the effect is not significant. $\mathrm{K}$ substance has particular feature compares to another substances, where the $\mathrm{K}$ surplus in soil does not have negative impact on crop. This evokes the loss of $\mathrm{K}$ in soils is higher than any assumption because crop can absorb $\mathrm{K}$ more than its real requirement.

Efforts to upgrade crop productivity through fertilization are often inhibited by the expensive price of synthetic chemical fertilizer or its scarce availability in markets. Therefore, one solution to look for alternative fertilizer which can substitute the using of synthetic chemical fertilizer with lower price and convenience to obtain is taking advantage of crop wastes. Crop waste is the source of organic matter to soils. The using of crop waste as fertilizer is convenient to be conducted because it is available in the surrounding nature. Coconut fibre is an example of crop waste which is able to be applied as organic fertilizer (Oktavia, 2013). Coconut fibre contains high $\mathrm{K}$ elements, therefore it can be utilized as $\mathrm{K}$ source in processing as $\mathrm{K}$ fertilizer. The extraction of $\mathrm{K}$ substances from agricultural waste is 
conducted through the making of ash, so that the organic salts which are contained in the ash can be modified into carbonate kalium (Maesaroh et al, 2014).

Ekawati and Purwanto (2012) pointed out that coconut fibre contained $10.25 \%$ of $\mathrm{K}$. In addition, coconut fibre also contains any other carbohydrate compounds such as pectin (14.06 $\%)$, hemicellulose $(7.69 \%)$, lignin $(30.02 \%)$, and cellulose (Maesaroh et al, 2014). The result of study performed by Maruapey and Faesal (2010) indicated that $\mathrm{KCl}$ fertilizer dosage $100 \mathrm{~kg} / \mathrm{ha}$ provided the highest waxy corn production as many as $4.35 \mathrm{ton} / \mathrm{ha} . \mathrm{KCl}$ dosage of $75 \mathrm{~kg} / \mathrm{ha}$ had significant effect on crop height, where at the age of 4 weeks after planting (WAP) was obtained the average height of $91.82 \mathrm{~cm}$, and at $8 \mathrm{WAP}$ the average height was $199.46 \mathrm{~cm} . \quad \mathrm{KCl}$ dosage of 100 $\mathrm{kg} / \mathrm{ha}$ resulted the fastest flowering period as many as 29 days after planting (DAP), the average of amilopectin content of $74.21 \%$, and the highest biomass as many as 11.01 ton/ha.

Risnah et al (2013) reported that the utilization of coconut ash as alternative to $\mathrm{KCl}$ fertilizer could raise $\mathrm{K}$ availability in soils and $\mathrm{K}$ absorption on cacao seedling growth. The dosage of coconut ash organic fertilizer as many as $39.25 \mathrm{~g}$ per crop raised effectively the available $\mathrm{K}$ in soil until the age of cacao seedling reached 4 months after planting. The average of available $\mathrm{K}$ amount at the application of ash $39.25 \mathrm{~g}$ achieved $2.66 \mathrm{me} /$ $100 \mathrm{~g}$ soils. Jumin (2010) argued that K availability in soil was said to be high if the content was above $0.64 \mathrm{me} / 100 \mathrm{~g}$ soil. Ash dosage of $39.25 \mathrm{~g}$ also resulted highest $\mathrm{K}$ absorption on plant tissues such as leaf, stem, and root as many as $12.35 \mathrm{mg} / \mathrm{plant}$.

The result of study by Risnah et al (2013) also indicated that after the application of coconut ash organic fertilizer there was a $\mathrm{pH}$ increasing in planting medium. The increasing of $\mathrm{pH}$ was probably because coconut ash had high $\mathrm{pH}$ and dominated by base ion of $\mathrm{OH}^{-}$. After applying on inceptisol soil planting medium which had more $\mathrm{H}^{+}$ions, coconut ash application could incline $\mathrm{OH}^{-}$ion concentration. Thus, both the concentrations of $\mathrm{H}^{+}$and $\mathrm{OH}^{-}$ions in soil solvent became more balance and resulting the neutral $\mathrm{pH}$. Appliaction of coconut ash with dosage 39.25 $\mathrm{g}$ per plant gave average soil $\mathrm{pH}$ of 7.05 . Besides, the result of coconut ash analysis conducted by Risnah et al (2013) demonstrated that coconut ash had good cation exchange capacity (CEC) with value of 13.29 me/100 g. Soemeinaboedhy and Tejowulan (2007) clarified that the higher the CEC value, the more the cation exchange, and this meant that the substance release would be higher too. Thus, coconut ash constitutes potential stuff for being an organic fertilizer to crops.

Research done by Nurmas (2008) discovered that coconut ash fertilizer with dosages between 1.0 and 2.5 ton/ha gave significant difference on cucumber growth components such as stem diameter and leaf size and yield components such as the length and weight of fresh fruit. This is because coconut ash application is capable of improving physical feature of soil, neutralizing soil $\mathrm{pH}$, and providing nutrient to crops. Hermawati (2007) noted that coconut ash with dosage of 3 ton/ha showed a significant effect on the growth and yield of water melon which covered observation components such as total leaf size, root dry weight, the age of first flower formation, and fruit weight.

Another investigation that was undertaken by Maesaroh et al (2014) found that coconut ash extract with concentration of $100 \mathrm{ml}$ gave significant difference at initial growth of sweet corn which comprised crop height and the amount of leaf. According to Nurvitha (2016), K played role in the synthesis of protein and carbohydrate, where $\mathrm{K}$ was absorbed by plant in the form of $\mathrm{K}^{+}$, mainly on young cells or on crop parts which contained much proteins.

\section{RESEARCH METHOD}

\section{Study Time and Site}

This research was conducted in July to September 2017 at Experiment Garden Faculty of Agriculture Tentena Christian University. Laboratory tests were performed at Soil Science Laboratory and Food Production Technology Laboratory, Faculty of Agriculture Tadulako University Palu in September to October 2017. 


\section{Materials and Devices}

Materials used in this study were waxy corn seeds of local variety, coconut fibre, animal manure, firewood, Furadan 3G insecticide, and Dithane M-45 fungicide. Devices used included analytical scales, metric tool, hoe, harrow, sprayer, dibble, drum, and treatment label boards.

\section{Research Implementation Organic Fertilizer Chemical Analysis}

Analysis against coconut ash organic fertilizer was done by measuring $\mathrm{pH}$, total $\mathrm{K}$, organic $\mathrm{C}$, cation exchange capacity, water content, and $\mathrm{C} / \mathrm{N}$ ratio.

\section{The Making of Coconut Ash}

Coconut fibres were splitted into small parts to make the burning easier. After being splitted, fibres were put into drum and piled one by one. Firewoods were put at the drum base, while the mouth of the drum was closed so that the fibre burning carried out slowly in order to obtain ash with good quality. Ash which was formed from burning process then was cooled off.

\section{Land Preparation and Planting}

Land was plowed, hoed, harrowed, mixed with manure, and formed into ditches with size $2.1 \times 1.5 \mathrm{~m}$. Ashes were mixed with soils according to dosage that has been determined for every treatment ditch. Ditch was then being abandoned for 3 days before planting was conducted. Waxy corn seeds were planted by dibbling. Planting space $40 \times 30 \mathrm{~cm}$ was used in this experiment.

\section{Treatment Application}

Treatments of coconut ash fertilizer dosage in this study consist of ash dosages of :

$\mathrm{A}_{0} \quad=0.00$ ton $/ \mathrm{ha}$

$\mathrm{A}_{1} \quad=0.75$ ton $/ \mathrm{ha}$

$\mathrm{A}_{2}=1.50$ ton $/ \mathrm{ha}$

$\mathrm{A}_{3}=2.25$ ton $/ \mathrm{ha}$

$\mathrm{A}_{4}=3.00$ ton $/ \mathrm{ha}$

$\mathrm{A}_{5} \quad=3.75$ ton $/ \mathrm{ha}$

$\mathrm{A}_{6} \quad=4.50$ ton $/ \mathrm{ha}$

There were 7 treatment ditches in which every treatment was repeated 3 times, therefore there were 21 experiment units overall.

\section{Cultivation and Harvesting}

Crop cultivation included watering, weeding, and controlling of pests and diseases.
Harvesting was done when crops had reached the age of 80 days after planting.

\section{Observation Components} were :

Components which observed in this study

1. Yield components, comprised of ear height position from soil surface $(\mathrm{cm})$, the number of ear per crop, ear length $(\mathrm{cm})$, the number of seed row on ear, the number of seed per ear, the ear weight with and without dried husk (g), and waxy corn production with and without dried husk (g).

2. Quality components, comprised of starch content $(\%)$, amilose content $(\%)$, and amilopectin content (\%).

\section{Data Analysis}

Data which had been compiled was then analyzed using one way analysis of variance, $t$ test for 2 independent saamples, and simple linear regression with equation model : $\mathrm{Y}=\mathrm{a}+\mathrm{bX}$

\section{RESULT AND DISCUSSION}

\section{Chemical Analysis of Organic Fertilizer}

Based on laboratory tests it was obtained the result of organic fertilizer chemical analysis as follows :

Table 1. The result of chemical analysis for coconut ash organic fertilizer

\begin{tabular}{clrc}
\hline No. & Parameter & Value & Unit \\
\hline 1. & $\mathrm{pH}$ & 9.69 & - \\
2. & Total K & 10.12 & $\%$ \\
3. & Organic C & 11.24 & $\%$ \\
4. & CEC & 20.72 & $\mathrm{cmol}(+) \mathrm{kg}^{-1}$ \\
5. & Water & 29.63 & $\%$ \\
6. & C/N Ratio & 36.65 & - \\
\hline
\end{tabular}

The minimal technically requirements of solid organic fertilizer in the form of crumbs according to Indonesian Ministry of Agriculture (2011) is as follows : 
Table 2. The minimal technically requirements of solid organic fertilizer in the forms of crumbs

\begin{tabular}{|c|c|c|c|}
\hline No. & Parameter & Value & Unit \\
\hline 1. & $\mathrm{pH}$ & $4-9$ & - \\
\hline 2. & Total K & $\underset{4}{\operatorname{minimal}}$ & $\%$ \\
\hline 3. & Organic C & $\underset{15}{\operatorname{minimal}}$ & $\%$ \\
\hline 4. & CEC & - & $\underset{1}{\operatorname{cmol}(+) \mathrm{kg}^{-}}$ \\
\hline 5. & Water & $15-25$ & $\%$ \\
\hline 6. & C/N Ratio & $15-25$ & - \\
\hline
\end{tabular}

Comparation between data on Table 1 and Table 2 shows that there are some parameters in Table 1 which values do not meet the quality standard as determined in Table 2. This means that for being an organic fertilizer product with good quality and satisfying minimal technically requirements, coconut ash processing needs to be studied and assesed further in order to obtain a standard procedure, and its tested parameters are also able to meet spesifications that suit to government regulation.

Generally it can be seen that coconut ash has base nature with $\mathrm{pH}$ of 9.69. Therefore it is potential to increase $\mathrm{pH}$ to soils with high acidity level such as turf soils (Nurvitha, 2016), red yellow podzolic soils (Hermawati, 2007), or ultisol soils (Farizaldi, 2014). The value of total $\mathrm{K}$ as many as $10.12 \%$ means that coconut ash contains kalium nutrient in high amount, although its organic matter content is low $(11.24 \%)$.

Cation exchange capacity of coconut ash as many as $20,72 \mathrm{cmol}(+) \mathrm{kg}^{-1}$ is high enough if compared to another materials such as wood $\left(3,47 \mathrm{cmol}(+) \mathrm{kg}^{-1}\right)$, rice husk $(16,70$ cmol $\left.(+) \mathrm{kg}^{-1}\right)$, or sawdust $\left(18,36 \mathrm{cmol}(+) \mathrm{kg}^{-1}\right)$. Soemeinaboedhy and Tedjowulan (2007) confirmed that coconut ash had total surface size which was bigger than another materials thus it had more surface that possible to do cation exchange. Water content of coconut ash with value of $29.63 \%$ is higher than quality standard which has value between 15 and 25 $\%$. It is assumed that it associates with the nature of coconut fibre which is easy to absorb and store water (Lestari, 2016). Moreover,
Dianawati (2014) stated that coconut ash had high porousity, which meant it was able to bind liquid in its pores.

$\mathrm{C} / \mathrm{N}$ ratio in coconut ash with value of $36.65 \%$ which is also higher than quality standard $(15-25 \%)$ indicates an unoptimal level of fertilizer maturity. Dewi and Tambingsila (2014) argued that $\mathrm{C} / \mathrm{N}$ ratio had effect on plant growth because to break organic matter on organic fertilizer, decomposer bacteria needed much more $\mathrm{N}$ nutrient.

\section{Yield Components of Waxy Corn}

1) Ear height position from soil surface

The result of one way analysis of variance demonstrates that the treatments of coconut ash dosage have significant effect on ear height position from soil surface, while the result of $t$ test for 2 independent samples is as follows :

Table 3. The average of ear height position from soil surface $(\mathrm{cm})$

\begin{tabular}{cr}
\hline Coconut ash dosage & \multicolumn{1}{c}{ Average } \\
\hline $\mathrm{A}_{0}(0.00$ ton/ha) & $64.33^{\mathrm{a}}$ \\
$\mathrm{A}_{1}(0.75$ ton/ha) & $108.00^{\mathrm{b}}$ \\
$\mathrm{A}_{2}(1.50$ ton/ha) & $97.33^{\mathrm{b}}$ \\
$\mathrm{A}_{3}(2.25$ ton/ha) & $107.67^{\mathrm{b}}$ \\
$\mathrm{A}_{4}(3.00$ ton/ha) & $91.00^{\mathrm{c}}$ \\
$\mathrm{A}_{5}(3.75$ ton/ha) & $93.33^{\mathrm{c}}$ \\
$\mathrm{A}_{6}(4.50$ ton/ha) & $90.83^{\mathrm{c}}$ \\
\hline Note $\quad:$ Numbers followed by the same \\
alphabet are not different significantly \\
on $\alpha=0.05$
\end{tabular}

The result of $t$ test shows that the highest average is obtained at $A_{1}$ treatment. The result of simple linear regression analysis depicts functional correspondence as shown in Figure 1. Higher ear position from soil surface relates to the increasing of both plant height and the number of leaf. $\mathrm{K}$ substance in fertilizer causes more optimal photosynthesis process so that plant can accumulate photosynthesis results more effectively, especially those from leaves locate above ear position. Ideal feature of waxy corn is that ear exists at middle position, that is, half of plant height (Maruapey and Faesal, 2010). 


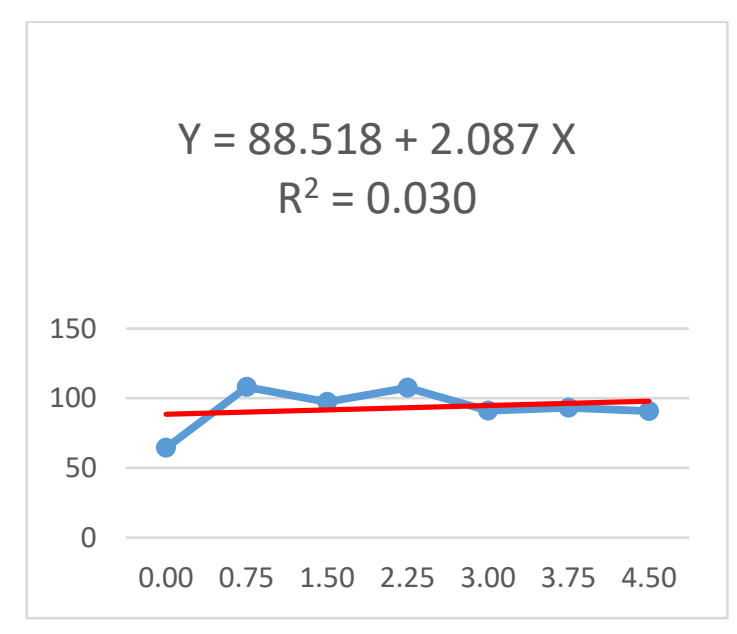

Figure 1. Correspondence between fertilizer dosage and ear height position

2) The number of ear per crop

The result of one way variance analysis points out that coconut ash dosage treatments have no significant effect on the number of ear per crop. This means that waxy corn crops have relatively same capability to form ear, although they are given fertilizer in different dosages. Besides that, it can be presumed that ear formation is more controlled genetically (Pandia et al, 2013).

\section{3) Ear length}

One way anova result indicates that fertilizer dosage treatments have no significant effect on ear length. Presumebly, the relative same measure of ear length is influenced by plant genetic factors and supported by environment condition which is relatively not different.

4) The number of seed row on ear

The result of one way anova clarifies that treatments of fertilizer dosage have significant effect on the number of seed row on ear. The result of 2 sample $t$ test is given in Table 4 . The result of $t$ test shows that the highest average is obtained at $\mathrm{A}_{1}$ treatment (13.33). Simple linear regression result is given in Figure 2.
Table 4 . The average of the number of seed row on ear

\begin{tabular}{cr} 
Coconut ash dosage & \multicolumn{2}{c}{ Average } \\
\hline $\mathrm{A}_{0}(0.00$ ton/ha) & $10.00^{\mathrm{a}}$ \\
$\mathrm{A}_{1}(0.75$ ton/ha) & $13.33^{\mathrm{b}}$ \\
$\mathrm{A}_{2}(1.50$ ton $/ \mathrm{ha})$ & $12.67^{\mathrm{b}}$ \\
$\mathrm{A}_{3}(2.25$ ton $/ \mathrm{ha})$ & $13.00^{\mathrm{b}}$ \\
$\mathrm{A}_{4}(3.00$ ton $/ \mathrm{ha})$ & $11.67^{\mathrm{c}}$ \\
$\mathrm{A}_{5}(3.75$ ton $/ \mathrm{ha})$ & $12.00^{\mathrm{c}}$ \\
$\mathrm{A}_{6}(4.50$ ton $/ \mathrm{ha})$ & $12.00^{\mathrm{c}}$ \\
\hline
\end{tabular}

Note : Numbers followed by the same alphabet are not different significantly on $\alpha=0.05$

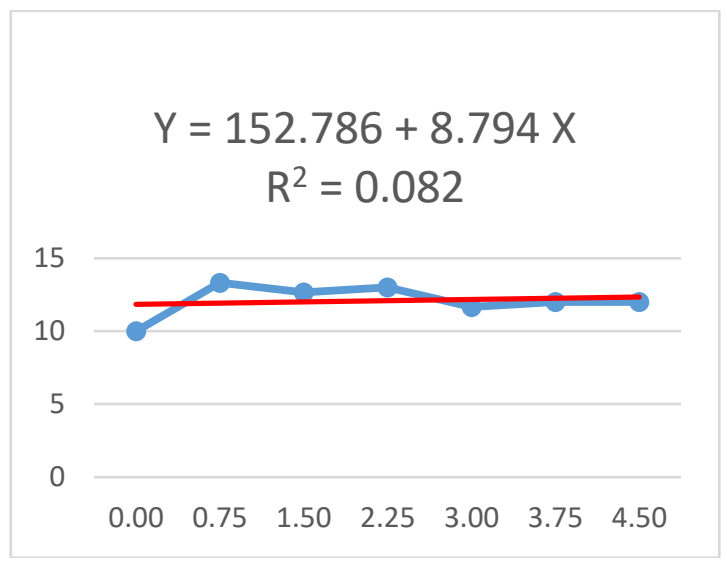

Figure 2. Correspondence between fertilizer dosage and the number of seed row

The more optimal photosynthesis process along with the increasing of the number of $\mathrm{K}$ applied to soil induces a greater distribution of photosyntate in the form of carbohydrate to economic part of waxy corn, namely the ear part. This is signaled in more seed rows shape on the ear. The formation of seed rows on ear constitutes accumulation of food reserve which is translocated from leaves to waxy corn seeds (Maruapey and Faesal, 2010).

5) The number of seed per ear

The result of one way anova indicates that treatments of coconut ash fertilizer dosage are not significantly different on the number of seed per ear. Different fertilizer dosages do not influence plant ability in shaping seeds on ear. 
6) Ear weight with dried husk

The result of one way anova points out that fertilizer dosage treatments give significant effect on ear weight with dried husk. Result for 2 independent sample $t$ test is as follows :

Table 5. The average ear weight with dried husk (g)

\begin{tabular}{cr} 
Coconut ash dosage & \multicolumn{1}{c}{ Average } \\
\hline $\mathrm{A}_{0}(0.00$ ton $/ \mathrm{ha})$ & $106.00^{\mathrm{a}}$ \\
$\mathrm{A}_{1}(0.75$ ton $/ \mathrm{ha})$ & $165.33^{\mathrm{b}}$ \\
$\mathrm{A}_{2}(1.50$ ton $/ \mathrm{ha})$ & $176.33^{\mathrm{b}}$ \\
$\mathrm{A}_{3}(2.25$ ton $/ \mathrm{ha})$ & $242.67^{\mathrm{c}}$ \\
$\mathrm{A}_{4}(3.00$ ton $/ \mathrm{ha})$ & $183.67^{\mathrm{b}}$ \\
$\mathrm{A}_{5}(3.75$ ton $/ \mathrm{ha})$ & $176.00^{\mathrm{b}}$ \\
$\mathrm{A}_{6}(4.50$ ton $/ \mathrm{ha})$ & $158.00^{\mathrm{b}}$ \\
\hline
\end{tabular}

Note : Numbers followed by the same alphabet are not different significantly on $\alpha=0.05$

The result of $t$ test indicates that the highest average is achieved at $\mathrm{A}_{3}$ treatment $(242.67 \mathrm{~g})$ which is significantly different from five other treatments. This confirms the contribution of $\mathrm{K}$ substance in raising the carbohydrate formation through photosynthesis process. The increasing of photosynthesis rate causes tied $\mathrm{CO}_{2}$ is more than released $\mathrm{CO}_{2}$ in respiration process. Thus, resulting assimilates have more effects on the enhancing of ear weight on plant (Lakitan, 2011).

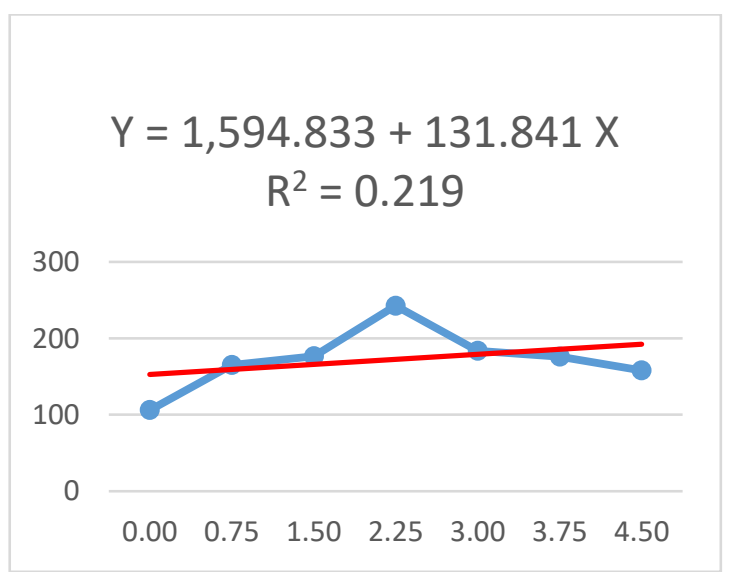

Figure 3. Correspondence between fertilizer dosage and ear weight with dried husk
7) Ear weight without dried husk

One way anova result confirms that fertilizer dosage treatments have significant effect on ear weight without dried husk. The result of $t$ test of 2 independent samples is as follows :

Table 6. The average of ear weight without dried husk (g)

\begin{tabular}{cr} 
Coconut ash dosage & \multicolumn{1}{c}{ Average } \\
\hline $\mathrm{A}_{0}(0.00$ ton/ha) & $67.00^{\mathrm{a}}$ \\
$\mathrm{A}_{1}(0.75$ ton/ha) & $96.33^{\mathrm{b}}$ \\
$\mathrm{A}_{2}(1.50$ ton $/ \mathrm{ha})$ & $115.33^{\mathrm{bd}}$ \\
$\mathrm{A}_{3}(2.25$ ton/ha) & $127.67^{\mathrm{cd}}$ \\
$\mathrm{A}_{4}(3.00$ ton $/ \mathrm{ha})$ & $112.00^{\mathrm{b}}$ \\
$\mathrm{A}_{5}(3.75$ ton $/ \mathrm{ha})$ & $105.00^{\mathrm{b}}$ \\
$\mathrm{A}_{6}(4.50$ ton $/ \mathrm{ha})$ & $121.00^{\mathrm{c}}$ \\
\hline
\end{tabular}

Note : Numbers followed by the same alphabet are not different significantly on $\alpha=0.05$

Result of $\mathrm{t}$ test shows that the highest average is obtained at $\mathrm{A}_{3}$ treatment $(127.67 \mathrm{~g})$. The result of simple linear regression is given below :

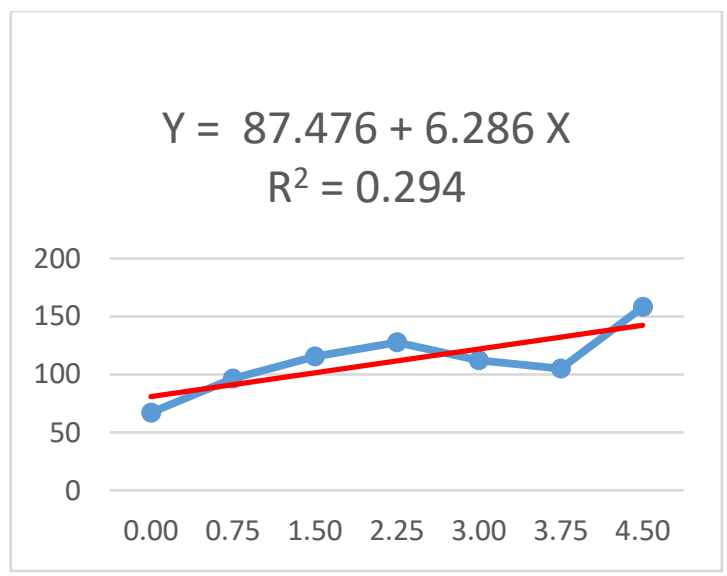

Figure 4. Correspondence between fertilizer dosage and ear weight without dried husk

Fertilizer application gives more effect on the increasing of ear weight than on husk weight. Kalium element in coconut ash fertilizer induces greater seed filling with carbohydrates, so that seed size becomes bigger, ear is filled densely with seeds, and then ear weight augments. 
8) Waxy corn production with dried husk

The result of one way anova demonstrates that fertilizer dosage treatments have significant effect on waxy corn production with dried husk. The result of $t$ test is shown as follows :

Table 7. The average waxy corn production with dried husk (ton/ha)

\begin{tabular}{cr} 
Coconut ash dosage & \multicolumn{2}{c}{ Average } \\
\hline $\mathrm{A}_{0}(0.00$ ton $/ \mathrm{ha})$ & $3.63^{\mathrm{a}}$ \\
$\mathrm{A}_{1}(0.75$ ton $/ \mathrm{ha})$ & $6.75^{\mathrm{b}}$ \\
$\mathrm{A}_{2}(1.50$ ton $/ \mathrm{ha})$ & $6.13^{\mathrm{b}}$ \\
$\mathrm{A}_{3}(2.25$ ton $/ \mathrm{ha})$ & $6.40^{\mathrm{b}}$ \\
$\mathrm{A}_{4}(3.00$ ton $/ \mathrm{ha})$ & $5.64^{\mathrm{c}}$ \\
$\mathrm{A}_{5}(3.75$ ton $/ \mathrm{ha})$ & $6.84^{\mathrm{b}}$ \\
$\mathrm{A}_{6}(4.50$ ton $/ \mathrm{ha})$ & $6.66^{\mathrm{b}}$ \\
\hline
\end{tabular}

Note : Numbers followed by the same alphabet are not different significantly on $\alpha=0.05$

The result of $t$ test points out that treatments of $\mathrm{A}_{1}$ to $\mathrm{A}_{4}$ yield the average production which are significantly different from $\mathrm{A}_{0}$, where the highest average exists at $\mathrm{A}_{5}$ treatment (6.84 ton/ha). Simple linear regression result is shown as follows :

$$
\begin{gathered}
Y=1,224.115+150.922 X \\
R^{2}=0.350
\end{gathered}
$$

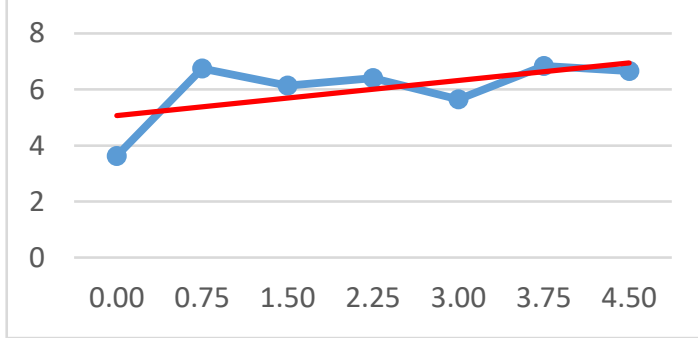

Figure 5. Correspondence between fertilizer dosage and corn production with dried husk

9) Waxy corn production without dried husk

One way anova result indicates that fertilizer dosage treatments give significant effect on waxy corn production without dried husk, while $t$ test result is provided below :
Table 8 . The average waxy corn production without dried husk (ton/ha)

\begin{tabular}{cr} 
Coconut ash dosage & Average \\
\hline $\mathrm{A}_{0}(0.00$ ton/ha) & $2.39^{\mathrm{a}}$ \\
$\mathrm{A}_{1}(0.75$ ton $/ \mathrm{ha})$ & $5.06^{\mathrm{b}}$ \\
$\mathrm{A}_{2}(1.50$ ton $/ \mathrm{ha})$ & $5.05^{\mathrm{b}}$ \\
$\mathrm{A}_{3}(2.25$ ton $/ \mathrm{ha})$ & $5.37^{\mathrm{b}}$ \\
$\mathrm{A}_{4}(3.00$ ton $/ \mathrm{ha})$ & $4.71^{\mathrm{c}}$ \\
$\mathrm{A}_{5}(3.75$ ton $/ \mathrm{ha})$ & $5.94^{\mathrm{b}}$ \\
$\mathrm{A}_{6}(4.50$ ton $/ \mathrm{ha})$ & $5.82^{\mathrm{b}}$ \\
\hline
\end{tabular}

\section{Note : Numbers followed by the same alphabet are not different significantly on $\alpha=0.05$}

The result of $t$ test points out that the highest average exists at $\mathrm{A}_{5}$ treatment (5.94 ton/ha). The role of kalium in improving crop growth and yield can be observed in the inclining of waxy corn production with and without dried husk. The increasing of coconut ash dosage causes physiology process in plant works better. It is due to the role of $\mathrm{K}$ as enzyme activator which is important in some physiological reactions, causes an optimal photosyntate accumulation, thus yields a heavier crop biomass (Pandia et al, 2013).

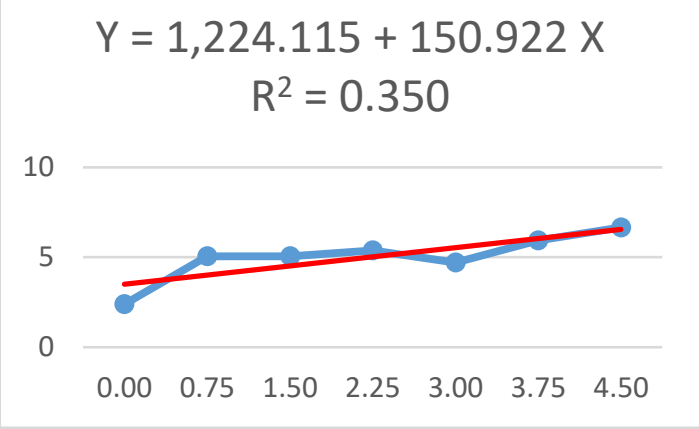

Figure 6. Correspondence between fertilizer dosage and corn production without dried husk

\section{Quality Components of Waxy Corn}

1) Starch content in waxy corn seed

One way anova result verifies that fertilizer dosage treatments have significant effect on starch content in waxy corn seed. Result of $\mathrm{t}$ test appears as follows : 
Table 9. The average of starch content (\%)

\begin{tabular}{cr} 
Coconut ash dosage & \multicolumn{1}{c}{ Average } \\
\hline $\mathrm{A}_{0}(0.00$ ton/ha) & $25.884^{\mathrm{a}}$ \\
$\mathrm{A}_{1}(0.75$ ton $/ \mathrm{ha})$ & $26.631^{\mathrm{b}}$ \\
$\mathrm{A}_{2}(1.50$ ton $/ \mathrm{ha})$ & $30.257^{\mathrm{c}}$ \\
$\mathrm{A}_{3} 1.25$ ton/ha) & $38.749^{\mathrm{d}}$ \\
$\mathrm{A}_{4}(3.00$ ton $/ \mathrm{ha})$ & $38.812^{\mathrm{d}}$ \\
$\mathrm{A}_{5}(3.75$ ton $/ \mathrm{ha})$ & $51.892^{\mathrm{e}}$ \\
$\mathrm{A}_{6}(4.50$ ton/ha) & $50.587^{\mathrm{f}}$ \\
\hline Note $\quad:$ Numbers followed by the same \\
\multicolumn{2}{c}{ alphabet are not different significantly } \\
on $\alpha=0.05$
\end{tabular}

The result of $t$ test shows that $\mathrm{A}_{5}$ treatment gives the highest starch content $(51.892 \%)$ which is significantly different from another treatments. Physiologically, kalium contained in coconut ash functions in forming and transporting carbohydrates into plant seeds. If plant lacks of kalium then carbohydrate accumulation will occur at leaves and this will reduce starch content in seed (Maruapey and Faesal, 2010). Starch is a main component in corn seed, composes about $70 \%$ of seed weight (Yassin et al, 2014).

$$
\begin{gathered}
Y=23.308+4.752 X \\
R^{2}=0.922
\end{gathered}
$$

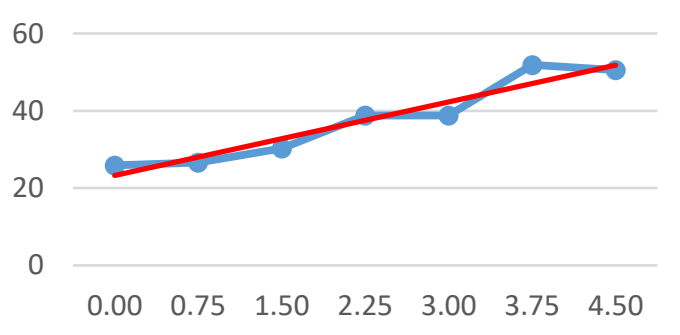

Figure 7. Correspondence between fertilizer dosage and starch content in seed

2) Amilose content in waxy corn seed

Variance analysis result demonstrates that coconut ash dosage treatments have significant effect on amilose content in waxy corn seed. Result of $t$ test is shown below :
Table 10. The average amilose content (\%)

\begin{tabular}{cr} 
Coconut ash dosage & \multicolumn{1}{c}{ Average } \\
\hline $\mathrm{A}_{0}(0.00$ ton $/ \mathrm{ha})$ & $7.387^{\mathrm{a}}$ \\
$\mathrm{A}_{1}(0.75$ ton $/ \mathrm{ha})$ & $7.610^{\mathrm{b}}$ \\
$\mathrm{A}_{2}(1.50$ ton $/ \mathrm{ha})$ & $6.369^{\mathrm{c}}$ \\
$\mathrm{A}_{3}(2.25$ ton $/ \mathrm{ha})$ & $6.841^{\mathrm{d}}$ \\
$\mathrm{A}_{4}(3.00$ ton $/ \mathrm{ha})$ & $5.699^{\mathrm{e}}$ \\
$\mathrm{A}_{5}(3.75$ ton $/ \mathrm{ha})$ & $4.235^{\mathrm{f}}$ \\
$\mathrm{A}_{6}(4.50$ ton $/ \mathrm{ha})$ & $4.855^{\mathrm{g}}$ \\
\hline Note $\quad:$ Numbers followed by the same \\
\multicolumn{2}{c}{ alphabet are not different significantly } \\
on $\alpha=0.05$
\end{tabular}

Treatment of $\mathrm{A}_{5}$ gives the lowest amilose content in waxy corn seed (4.235\%), while the result of simple linear regression analysis can be seen below :

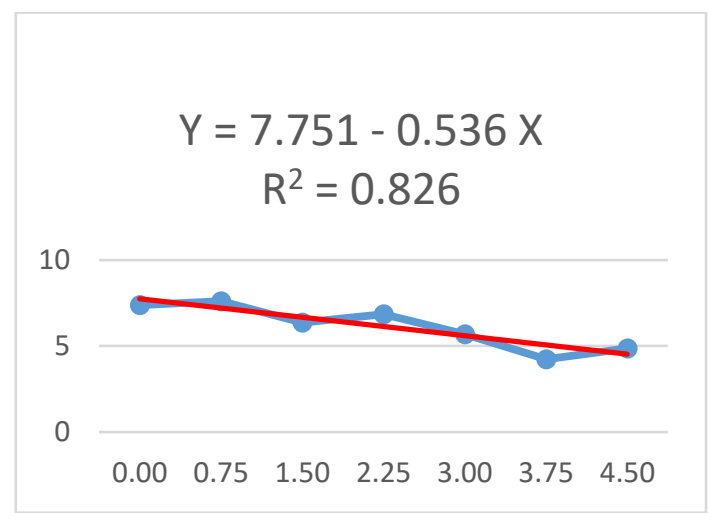

Figure 8. Correspondence between fertilizer dosage and amilose content in seed

Suarni and Yassin (2011) stated that starch in waxy corn seed comprises of two types of glucose polymer, namely amilose and amilopectin. Materials that contain high amilose content if boiled then the amilose will be extracted by heat water, and white color like milk will appear. Amilose composition in corn seed is controlled genetically, and generally, corn seed contains $25-30 \%$ amilose. Study result discovers that amilose content which exists in waxy corn seed ranges 4 to $7 \%$. Although controlled genetically, yet environmental factor such as fertilization presumably influences amilose content in corn seed. The higher coconut ash dosage, the more kalium absorbed by plant, and ultimately the lower the amount of amilose which is formed in starch. 
3) Amilopectin content in waxy corn seed

The result of one way anova indicates that coconut ash dosage treatments have significant effect on amilopectin content in waxy corn seed. Result of $t$ test is shown below :

Table 11. The average of amilopectin content (\%)

\begin{tabular}{cr} 
Coconut ash dosage & \multicolumn{1}{c}{ Average } \\
\hline $\mathrm{A}_{0}(0.00$ ton/ha) & $92.613^{\mathrm{a}}$ \\
$\mathrm{A}_{1}(0.75$ ton/ha) & $92.390^{\mathrm{b}}$ \\
$\mathrm{A}_{2}(1.50$ ton/ha) & $93.631^{\mathrm{c}}$ \\
$\mathrm{A}_{3}(2.25$ ton $/ \mathrm{ha})$ & $93 / 159^{\mathrm{d}}$ \\
$\mathrm{A}_{4}(3.00$ ton/ha) & $94.301^{\mathrm{e}}$ \\
$\mathrm{A}_{5}(3.75$ ton $/ \mathrm{ha})$ & $95.765^{\mathrm{f}}$ \\
$\mathrm{A}_{6}(4.50$ ton/ha) & $95.145^{\mathrm{g}}$ \\
\hline Note $\quad:$ Numbers followed by the same \\
alphabet are not different significantly \\
on $\alpha=0.05$
\end{tabular}

The result of $t$ test shows that $\mathrm{A}_{5}$ treatment gives the highest average of amilopectin content in waxy corn seed $(95.765 \%)$. The result of simple linear regression analysis is as follows :

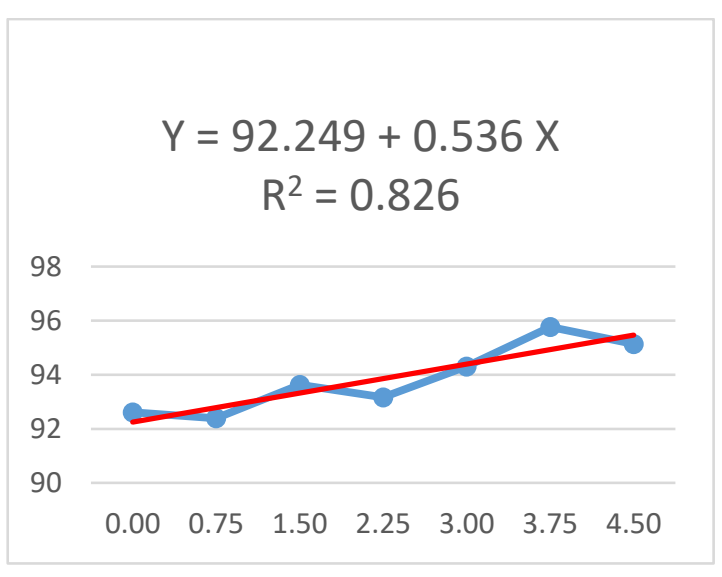

Figure 9. Correspondence between fertilizer dosage and amilopectin content in seed

Amilopectin is one type of glucose polymers exists in the starch of waxy corn seed. The comparation of compositions between amilose and amilopectin is $25-30 \%$ amilose and $70-75 \%$ amilopectin, but in waxy corn, amilopectin content can even reach until $100 \%$. Similarly to amilose, amilopectin content in waxy corn seed is controlled genetically. However, environment provides roles in the appearance of real characters which is stored in genes (Maruapey and Faesal, 2010). Therefore, the effect of environmental factors such as coconut ash fertilization is presumed to play roles in enhancing amilopectin content in waxy corn seed. The more the amilopectin content, the softer, stickier, and more delicious the texture and taste of waxy corn.

\section{CONCLUSION AND RECOMMENDATION}

\section{Conclusion}

1) The treatments of coconut ash organic fertilizer have significant effect on variables of ear height position from soil surface, the number of seed row on ear, ear weight with and without dried husk, waxy corn production with and without dried husk, and the contents of starch, amilose, and amilopectin in seed.

2) The treatment of coconut ash dosage as many as 0.75 ton/ha gives the highest average on variables of ear height position from soil surface and the number of seed row on ear. Fertilizer dosage as many as 2.25 ton/ha gives highest average on variables of ear weight with and without dried husk. Fertilizer dosage as many as 3.75 ton/ha gives highest average on variables of waxy corn production with and without dried husk, starch and amilopectin contents, and the lowest average of amilose content in seed.

3) The increasing of fertilizer dosage will cause quantitative increasing on variables of ear height position from soil surface, the number of seed row on ear, ear weight with and without dried husk, waxy corn production with and without dried husk, and the contents of starch and amilopectin in seeds. On the contrary, the increasing dosage will cause decreasing of amilose content in seeds.

\section{Recommendation}

Further study is needed to explore the application of coconut ash organic fertilizer on soils that have high acidity level such as peat, red yellow podzolic, and ultisol soils to determine fertilizer effectivity in upgrading the chemical properties of soil. 


\section{ACKNOWLEDGEMENT}

We would like to thank Direktorat Riset dan Pengabdian Masyarakat (DRPM) Direktorat Jenderal Riset dan Pengembangan Kementerian Riset, Teknologi, dan Pendidikan Tinggi (Kemenristekdikti) Republik Indonesia for funding this research through the scheme of Penelitian Dosen Pemula in the year of 2017.

\section{REFERENCES}

Azrai, M., M.J. Mejaya, dan M. Jasin, 2009. Pemuliaan Jagung Khusus. Balai Penelitian Tanaman Serealia. Maros.

BPS Poso, 2013. Poso dalam Angka 2013. Badan Pusat Statistik Kabupaten Poso.

Dewi, E.S. dan Tambingsila, M., 2014. Kajian Peningkatan Serapan NPK pada Pertumbuhan dan Hasil Tanaman Jagung dengan Pemberian Kombinasi Pupuk Anorganik Majemuk dan Berbagai Pupuk Organik. Jurnal AgroPet Fakultas Pertanian Universitas Sintuwu Maroso. 11(1) : 1 $-12$.

Dianawati, M., 2014. Penggunaan Pupuk Kandang dan Limbah Organik sebagai Media Tanam Produksi Benih Kentang. Jurnal Agros. 16 (2) : 292 - 300.

Ekawati, I. dan Z. Purwanto, 2012. Potensi Abu Limbah Pertanian Sebagai Sumber Alternatif Unsur Hara Kalium, Kalsium, dan Magnesium Untuk Menunjang Kelestarian Produksi Tanaman. Prosiding Seminar Nasional Kedaulatan Pangan dan Energi Universitas Trunojoyo. 27 Juni 2012, Madura, Indonesia. Hal. 135 - 139.

Farizaldi, 2014. Pengaruh Pemberian Pupuk Kandang dan Abu Sabut Kelapa Terhadap Pertumbuhan Sentro (Centrosema pubescens) pada Ultisol. Jurnal Penelitian Universitas Jambi Seri Sains. 16 (1) : $71-76$.

Hermawati, T., 2007. Respon Tanaman Semangka (Citrullus vulgaris Schard.) Terhadap Pemberian Berbagai Dosis Abu Sabut Kelapa. Jurnal Agronomi Fakultas Pertanian Universitas Jambi. $11(2): 77-80$.
Jumin, H.B., 2010. Dasar-dasar Agronomi. Rajawali Press. Jakarta.

Kementan RI, 2011. Peraturan Menteri Pertanian RI tentang Pupuk Organik, Pupuk Hayati, dan Pembenah Tanah. Kementerian Pertanian Republik Indonesia. Jakarta.

Lakitan, B., 2011. Dasar-dasar Fisiologi Tumbuhan. Raja Grafindo Persada. Jakarta.

Lestari, E.B., 2016. Pengaruh Kombinasi Pupuk Kandang Sapi dan Abu Sabut Kelapa sebagai Pupuk Utama dalam Budidaya Tanaman Brokoli (Brassica oleracia L.). Planta Tropica Journal of Agro Science. 4 (2) : 95 - 100.

Maesaroh, S., S.M.R. Sedyawati, dan F.W. Mahatmanti, 2014. Pembuatan Pupuk $\mathrm{K}_{2} \mathrm{SO}_{4}$ dari Ekstrak Abu Serabut Kelapa dan Air Kawah Item. Indonesian Journal of Chemical Science. 3 (3) : 239 $-243$.

Maruapey, A. dan Faesal, 2010. Pengaruh Pemberian Pupuk $\mathrm{KCl}$ Terhadap Pertumbuhan dan Hasil Jagung Pulut (Zea mays ceratina L.). Prosiding Pekan Serealia Nasional. 26 - 30 Juli 2010, Maros-Makassar, Indonesia. Hal. $315-326$.

Nurhayati, A. Jamil, dan R.S. Anggraini, 2011. Potensi Limbah Pertanian Sebagai Pupuk Organik di Lahan Kering Dataran Rendah Iklim Basah. Jurnal Iptek Tanaman Pangan. 6 (2) : 193 202.

Nurmas, A., 2008. Pengaruh Abu Sabut Kelapa Sebagai Bahan Pengapuran Alternatif Terhadap Pertumbuhan dan Produksi Tanaman Mentimun pada Tanah PMK. Jurnal Warta Wiptek. 16 (2) : $79-82$.

Nurvitha. L., 2016. Pengaruh Abu dan Pupuk Kandang Terhadap Pertumbuhan dan Hasil Tanaman Ciplukan (Physalis angulata L.) pada Media Gambut. Jurnal Agrovigor. 9 (1) : $33-41$.

Oktavia, F., 2013. Peran Produk Olahan Sabut Kelapa Sebagai Penunjang Kelestarian Ekologi. Prosiding Konferensi Nasional Kelapa VIII. 21 Mei 2014, Jambi, Indonesia. Hal. $205-210$. 
Pandia, A., Bangun, M.K., dan Hasyim, H., 2013. Respons Pertumbuhan dan Produksi Beberapa Varietas Tanaman Jagung terhadap Pemberian Pupuk N dan K. Jurnal Online Agroteknologi. 1 (3) : $348-361$.

Pradana, G.B.S., T. Islami, dan N.E. Suminarti, 2015. Kajian Kombinasi Pupuk Fosfor dan Kalium pada Pertumbuhan dan Hasil Dua Varietas Tanaman Sorghum (Sorghum bicolor (L.) Moench). Jurnal Produksi Tanaman Fakultas Pertanian Universitas Brawijaya. 3 (6) : 464 471.

Risnah, S., P. Yudono, dan A. Syukur, 2013. Pengaruh Abu Sabut Kelapa Terhadap Ketersediaan K di Tanah dan Serapan K pada Pertumbuhan Bibit Kakao. Jurnal Ilmu Pertanian Fakutas Pertanian UGM. 16 (2) : 79 - 91.

Soemeinaboedhy, I.N. dan R.S. Tejowulan, 2007. Pemanfaatan Berbagai Macam Arang Sebagai Sumber Unsur Hara P dan K Serta Sebagai Pembenah Tanah. Jurnal Agroteksos Fakultas Pertanian Universitas Mataram. 17 (2) : 114 122.

Suarni, 2009. Komposisi Nutrisi Jagung Menuju Hidup Sehat. Prosiding Pekan Serealia Nasional. 26 - 30 Juli 2010, Maros-Makassar, Indonesia. Hal. 410 426.

Suarni, 2013. Pengembangan Pangan Tradisional Berbasis Jagung Mendukung Diversifikasi Pangan. Jurnal Iptek Tanaman Pangan. 8 (1) : $39-47$.

Suarni dan Yasin, M., 2011. Jagung Sebagai Sumber Pangan Fungsional. Jurnal Iptek Tanaman Pangan. 6 (1) : 41 - 56.

Yasin, M., Langgo, W., dan Faesal, 2014. Jagung Berbiji Putih Sebagai Bahan Pangan Pokok Alternatif. Jurnal Iptek Tanaman Pangan. 9 (2) : 108 - 117. 
